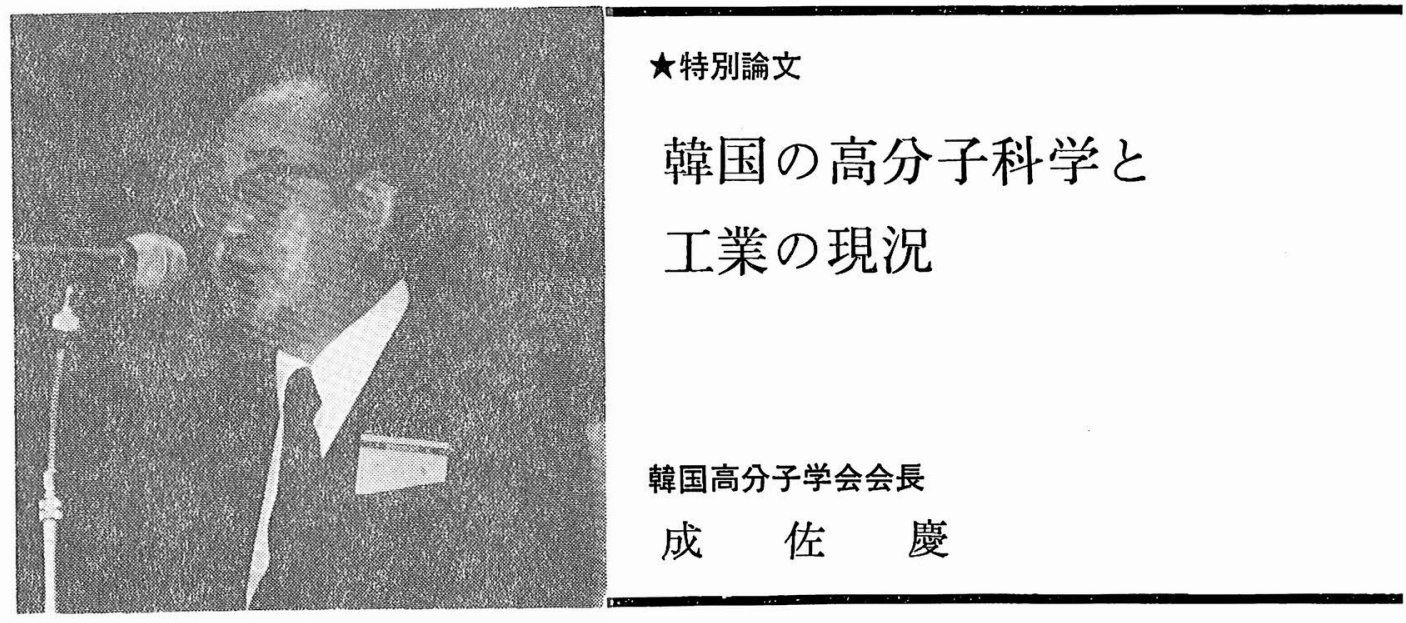

\section{1. 高分子工業}

国土はせまく，人口密度は高く，天然資源も豊かで ない韓国が，1962 年以来続いている 経済開発 5 力年 計画により, 最近 16 年間, 年平均 $10 \%$ 水準の経済成 長をしているのは工業発展によるものであり, その中 でも化学工業が特に目立っている. 高分子工業も驚く 速度で成長を続けている。

\section{1-1. 石油化学工業}

1961 年, 250 t/d の尿素肥料工場（忠洲）が生産を 始めたのが 石油原料化学工業の始まりといえる。' '64 年には, 最初の精油工場（蔚山）が 3.5 万 BPSD の 能力で操業を始め (現在の能力 21.5 万 BPSD), 続 いて，第二，第三の精油工場が建設され（現在の総精 油能力 57 万 BPSD), 輸入原料による PVC, ナイロ ソ, ポリエステル, アクリル䋐維生産工場が'70 年頃 まで各地に建設され，操業を開始した. '68 年には, 最初の石油化学工業団地が蔚山にて起工され, '72年工 チレン能力 10 万 $\mathrm{t}$ のナフサセンターが稼動し始め, 同時に PP, PE, VCM, AN 工場も生産を始め, 続い てアルキルベンゼン，カプロラクタム，PS 工場が'73 年末頃まで竣工した，需要增大のため各工場の拡張が 行なわれ, '77 年にはェチレン能力も 15.5 万 $\mathrm{t}$ 飞拡 張された。

蔚山石油化学工業団地の系統を第 1 図に示す、精油 工場の大韓石油公社がナフサセンターを運営し, 15 個 の会社が団地を構成し，石油化学支援工団を置いて二 一ティリティの供給管理と施設の維持管理を担当して いる. 団地付近には 2 個の肥料工場があり，ナフサの 供給を受け尿素を生産して括り，そのほか関連工場が

\footnotetext{
Trend of Polymer Research and Industry in Korea.
}

操業している.

石油化学工業製品の継続的需要增大により, '76 年 には麗水に第 2 石油化学工業団地の建設が始められ た．この麗川団地は第 2 図のごとく，エチンン 35 万 $\mathbf{t}$ 規模で現在稼動中のメタノール, PVC, ABS に加 えて,ナフサセンター, LDPE, HDPE, VCM, EG, $\mathrm{PP}$ などが'79 年上半期中に完工され, '80 年初めむ でにはラクタムを除きその他も操業開始の予定であ

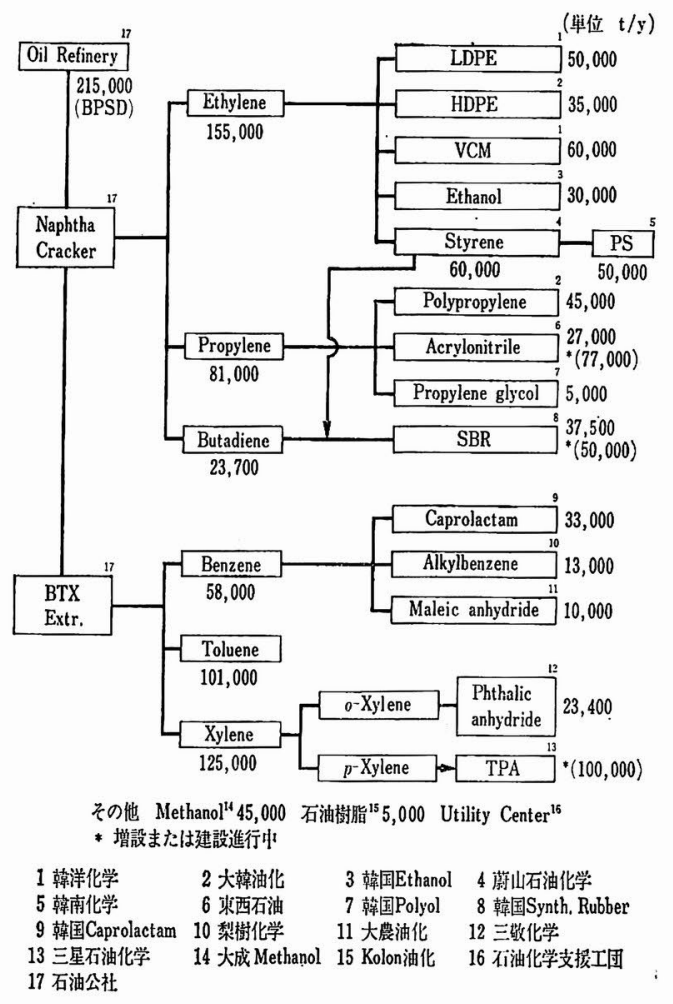

第 1 図啲山石油化学団地系統図 
第 1 表 年間高分子消費量（消費量 $1,000 \mathrm{t}$, 一人当たり消費量 $\mathrm{kg}$ ）

\begin{tabular}{|c|c|c|c|c|c|c|c|c|}
\hline \multirow{2}{*}{ 年度 } & \multicolumn{2}{|c|}{ Plastic*** } & \multicolumn{2}{|c|}{ 䋐 } & 维水** & \multicolumn{2}{|r|}{$\exists$} & \multirow{2}{*}{$\stackrel{\text { 厶 }}{\text { 学たり }}$} \\
\hline & 総 量 & 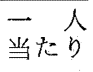 & 天然 & 合成 & 一当た令 & 天然 & 合成 & \\
\hline 1970 & 91.5 & 2.81 & 84.9 & 58.0 & $\begin{array}{r}\% \\
4.5 *(40)\end{array}$ & 26.1 & 12.1 & $\begin{array}{r}\% \\
1.2 *(32)\end{array}$ \\
\hline 1971 & 111.0 & 3.38 & 85.3 & 75.7 & $4.9(47)$ & 36.9 & 17.9 & $1.7(33)$ \\
\hline 1972 & 140.4 & 4.19 & 77.1 & 87.1 & $4.9(53)$ & 40.0 & 19.3 & $1.8(33)$ \\
\hline 1973 & 211.6 & 6.20 & 88.7 & 92.1 & $5.3(51)$ & 46.9 & 37.8 & $2,5(45)$ \\
\hline 1974 & 223.2 & 6.43 & 117.9 & 86.8 & $5.9(42)$ & 66.1 & 38.7 & $3.0(37)$ \\
\hline 1975 & 244.8 & 6.94 & & & & 68.1 & 39.9 & 3.1 (37) \\
\hline 1976 & 318.2 & 8.87 & & & & 80.9 & 62.8 & $4.0(44)$ \\
\hline
\end{tabular}

* カッ コ内合成品占有比率, ** PE, PVC, PP, PS だけの合計

****'75 年度合成䋐維総生産实績 $281,000 \mathrm{t}$

(プラスチック工業協会, 合成瀻維協会, 石油化学工業協会)

る.この団地には湖南精油のほか，尿素年産 26 万 $\mathrm{t}$, 複合肥料 70 万 $\mathrm{t}$ の南海化学が操業中で女る.

第 2 団地の竣工でも，需要に対応できないことが予 測され，今年 4 月に第 3 団地の計画が発表された，麗 川の第 2 団地に隣接してェチレン 35 万 $\mathrm{t}$ 規模の団地 を'82 年までた完工する計画で, $\mathrm{PE}, \mathrm{PP}, \mathrm{VCM}$, $\mathrm{SBR}$, スチレン，AN の注か䣫酸ビニル，酸化プロピ レンが含まれている。

\section{1-2. プラスチック}

輸入樹脂による小規模加工にすぎなかったプラスチ ック工業も，'66 年方ら'69 年にか子 5 個の PVC 生 産工場の完成により PVC の利用が開拓され, 石油化 学工業の成立につれ，ポリオレフィンを始め，プラス チックの消費が急増した，第 1 表のように，消費量は

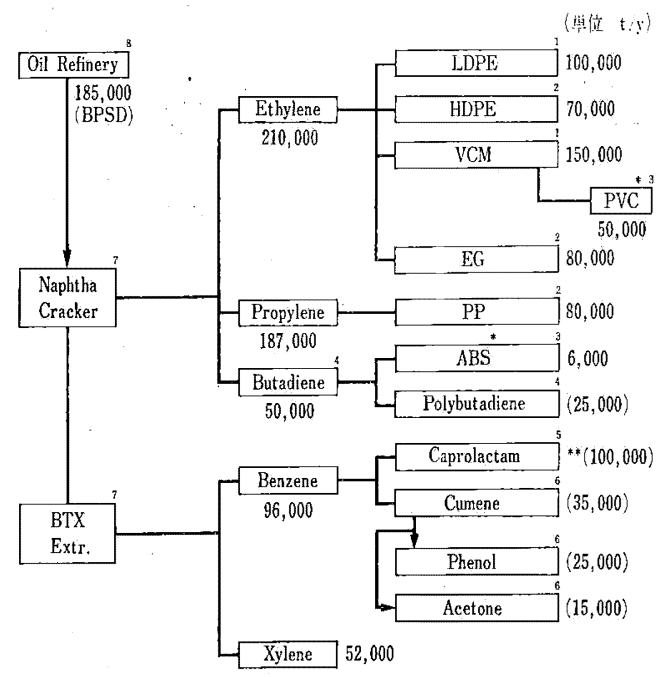

方他 Methanol ${ }^{9} 330,000$ 㙁素 ${ }^{10} 210,000$ カセイソー夕 ${ }^{10} 227,000 \mathrm{TDI}^{11}(10,000)$

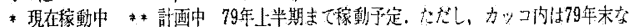
いL80年初完成手定

$\begin{array}{llll}1 \text { 韓洋化学 } & 2 \text { 湖南石油化学 } & 3 \text { (株)Lucky } & 4 \text { 韓国Synth. Rubber } \\ 5 \text { (現代) } & 6 \text { 錦湖化学 } & 7 \text { 湖南Ethylene } & 8 \text { 湖南精油 }\end{array}$ 9 大成Methanol 10 Korea Dow 11 准洋化学

第 2 図麗川石油化学団地系統図
第 2 表 汎用合成樹脂の需要と供給 (単位: $1,000 \mathrm{t}$ )

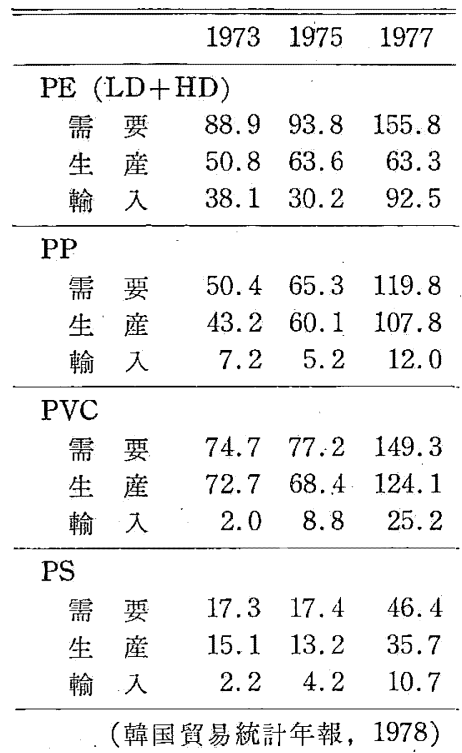

'70 年以来 $20 \%$ の比率で増加し, '73 年には実に 48 \%の增加を示した. '74, '75 年にはオイルショックの 影響で，4 特よび $8 \%$ の增加に止まったが，'76 年に は，再び $28 \%$ の増加を示した，四大沉用プラスチッ クの'77 年度需要林 47 万七こして招り，加工製品 輸出量を除外しても年間一人当たり消費量甠 $12 \mathrm{~kg}$ を 上回わって特り，その他の樹脂を合わせると，15kg 近 いと推定される．四大沉用プラスチックの需給関係は 第 2 表のごとく, '77 年《総 14 万 $\mathrm{t}$ 以上を翰入した. 来年第 2 石油化学団地が稼動すれば, 年間約 30 万 $\mathrm{t}$.

第 3 表 沉用以外の合成樹脂㧍よび原料の需給

(単位: $t$ )

\begin{tabular}{|c|c|c|c|c|}
\hline & \multicolumn{2}{|c|}{1970} & \multicolumn{2}{|c|}{1975} \\
\hline & 需 要 & 輸 入 & 需 要 & 輸 入 \\
\hline 素* & 2,238 & - & 6,740 & 一 \\
\hline メ ラ ミ ン* & 558 & 454 & 6,147 & 610 \\
\hline 石＼cjkstart炭＼cjkstart酸* & 1,336 & 1,336 & 2,950 & 2,950 \\
\hline 無水フタル酸 & 6,345 & 3,524 & 12,896 & 2,173 \\
\hline ポリウレタン & 42 & 42 & 3,575 & 601 \\
\hline $\begin{array}{lll}\mathrm{T} & \mathrm{D} & \mathrm{I}\end{array}$ & 777 & 777 & 2,253 & 2,253 \\
\hline エポキシ樹脂 & 110 & 110 & 1,948 & 947 \\
\hline シリコン樹脂 & 118 & 118 & 383 & 383 \\
\hline $\begin{array}{l}\text { ポリアミド, } \\
\text { ポリエスデル** }\end{array}$ & 191 & 191 & 5,225 & 5,225 \\
\hline 酢酸 ビ = ル & 2,228 & 2,228 & 4,218 & 4,218 \\
\hline$M \quad M \quad A$ & 7,337 & 7,337 & 9,016 & 9,016 \\
\hline メ夕, - & 36,945 & 25,945 & 84,857 & 39 \\
\hline
\end{tabular}

* 樹脂製造用のみ，合板接着剂用除外

*** 繊維用除外

（韓国貿易統計年報） 
第4 表 沉用プラスチックの製品別生産比率（\%)

\begin{tabular}{|c|c|c|c|c|c|c|c|c|c|c|c|c|c|}
\hline \multicolumn{3}{|c|}{ PVC } & \multicolumn{2}{|c|}{$\mathrm{PE}(\mathrm{LD}+\mathrm{HD})$} & \multicolumn{5}{|c|}{ PP } & \multicolumn{4}{|c|}{ PS } \\
\hline 電 & 線 被 覆 & 24.0 & $フ \quad 1$ ル & 71.8 & 織 & 造 & 包 & 装 & 30.6 & 電 & 気 部 & 品 & 34.2 \\
\hline \multirow{2}{*}{ 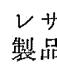 } & ザー括よび同 & 220 & 口 - $\quad$ プ, & 103 & $>$ & 1 & ル & $\Delta$ & 25.4 & 成 & 形 & 品 & 33.6 \\
\hline & & & フラットヤーン & & 成 & & & 形 & 23.6 & 包 & 装 & 材 & 12.5 \\
\hline シ & 一 r, 板 & 19.4 & 成形品 & 7.5 & 漁 & & $\square-$ & プ & 20.4 & 建 & & 材 & 6.4 \\
\hline ハீ & 1 & 8.7 & コーティング用 & 5.8 & & & & & & r & の & 他 & 13.3 \\
\hline$>$ & $1 ル ム$ & 5.0 & そ & 4.6 & & & & & & & & & \\
\hline & の & 20.9 & & & & & & & & & & & \\
\hline
\end{tabular}

（韓国合成樹脂工業協同組合）

の追加供給が可能であるが, 現在の趨勢で消費が増加 すれば'80 年には需要が生産を上回わると予測され る.

沉用以外の熱可塑性和よび熱硬化性樹脂の需要は, 約 5 万 $\mathrm{t}$ 程度で, これらおよびその原料の需給は第 3 表のごとくである、エポキシ，ケイ素樹脂，成形用ポ リアミド，ポリエステル，イオン交換樹脂などは生産 されて拈らず, 単量体の MMA, 酢酸ビニル, PG, TDI なども輸入されている. メラミンは'75 年以来 生産されて和り石炭酸は工場建設中である.

成形加工は数個の大規模のものを除き，だいたい中 小企業が主で, その業体数は 1,500 以上と推定される. ほとんどあらゆる成形加工方式が実施されており，大 容量でない簡単な射出, 押出, その他の成形機械も生 産されている. 第 4 表に四大沉用プラスチックの品種 別成形加工比率を示した. 総 80 万 $\mathrm{t}$ 以上の能力があ り，各種別品目別内訳と比率は外国と大差ない，プラ スチック製品の輸出も活発で, '76 年は 2 億 8,600 万 ドルに達し, 年々増加している。

\section{1-3. 合成緎維}

1963 年ナイロン 6 工場の完工以来, ’70 年までポリ エステル，ナイロン，アクリルなど 8 個の合成緎維工 場が建設され，その後増設・拡張が続き，第 5 表のよ らに最近 5 年間, 3 5.7 倍の生産能力の 増加を示し た.'77 年現在の総人造緎維生産能力は $944.3 \mathrm{t} /$ 日で あり,なお $200 〜 300 \mathrm{t} /$ 日の増設計画をもっている. 生産能力では, 世界 10 位以内に入り, 実地生産も '75 年度の年産 28.1 万 tで, 工場は活とんど完全稼 動している. 原料としてはラクタムと AN だけが生 産されているが, 需要を充足できず’77 年に括の新の 4.5 および 8.1 万t 輸入された. AN 工場の拡張 (7.7万 t ) が今年中に完成しても, 需要を満たしされ ない，建設中の TPA 10 万t が完成してもな特 5 万 $\mathrm{t}$ は不足の見込みである.

繊維製品の輸出が非常に活発で, 合成繊維生産量の 半分以上は輸出量である. 繊維消費量推移と天然和よ び人造繊維使用比率は第 1 表に示した通りである.
第 5 表 合成絒維生産能力增加趨茄 $(t / d)$

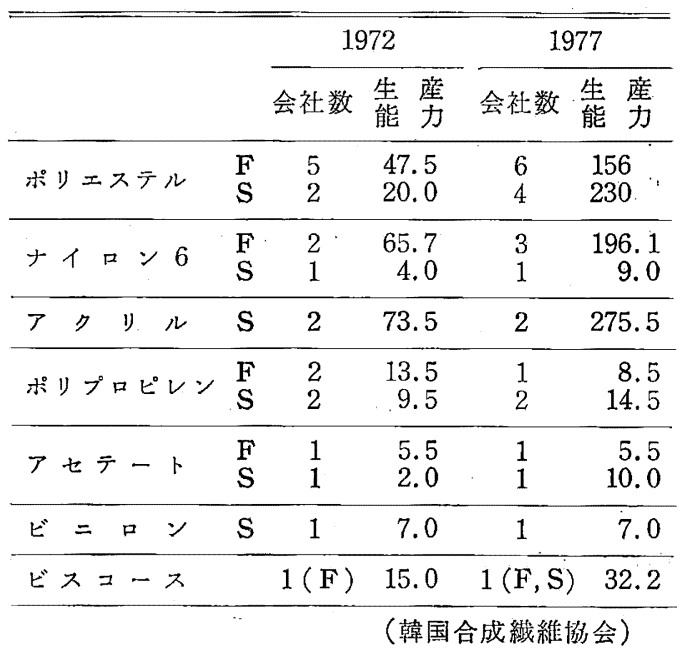

1-4. ゴム

総新ゴム使用量も最近 5 年間 3 倍以上増加し, 年 15 万 $\mathrm{t}$ を上回わっている. 合成ゴム生産能力は, SBR

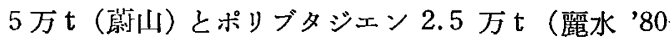
年生産）でめり，第1表のように合成ゴム使用比率は $50 \%$ 以下で, 使用增加の 余地が多い. ゴム楽品も加 硫促進剤, カーボンブラック，白カーボンなど多種生 産されている、ゴム製品もベルト，ホース，ローラ 一、ラテックス利用製品, 工盖用製品など多様であ る.ゴム鞉は 3,000 万足以上の能力をるつ 4 個の会社 を含め， 1,850 億足 ('75 年度) の能力をもち, タイヤ も380 万本の能力をもっている. '75 年度のタイヤと ゴム靴の輸出額は 2.8 億ドルであった.

\section{1-5. その他}

製紙工業は'75 年現在 85.8 万t の能力を有し, '81 年には 123.8 万 $\mathrm{t}$ の需要が予测されている. 木材資源 が貧弱で，14万 $\mathrm{t}$ 程度の砕木パルプと小規模の稲 straw パルプ工場のみであるが，輸入原木を使ら木材 和よび合板工場の廃材を原料とする日産 $300 \mathrm{t}$ の化学 パルプ工場が建設中である. 規模の大きい合板工場が 多数あり, 75 年に 35 億 $\mathrm{S} / \mathrm{F}, 2.4$ 億ドルの合板を 輸出した。接着剂はみな自家生産であり, ホルマリン 
工場ももっている.

塗料工場子群小合わせて約 40 に達し, 油性, 水性, 合成樹脂系を生産し，その能力も 4 万 $\mathrm{t}$ を上回わって いる. 皮革生産も'75 年 650 万 $\mathrm{m}^{2}$ の能力を有し, 牛原皮も 7.6 万 $\mathrm{t}$ 輸入し, 革製品輸出も 4 億ドルをこ した.

\section{1-6. 展 望}

韓国石油化学工業協会が昨年推定した高分子および その原料の長期予測を第 6 表に示す. プラスチックに 関しては, '81 年までは年平均 $20 \%$ 以上, 以後 5 力年 間は $10 \%$ 程度を推定した. '81 年特よび '86 年のプ ラスチック一人当たり需要量は, 各々 25 拉よび 40 $\mathrm{kg}$ 程度になる. 合成繊維に対してはプラスチックの ような高度伸長は期待されず, ' 81 年まで 7 8\%, '86 年まで 4 5 \%を推定し，ゴムと対しては’81 年まで $16 \sim 18 \%, 86$ 年まで $10 \%$ 程度伸びるとみている. この遛勢だとすれば, '80 年代末までの エチレン需要 は200万t 程度になるべきだと予想される。

\section{2. 高分子研究}

昨年春, 韓国高分子学会が創立され，6冊の会誌を 発刊し，現在 600 名の正会員をむつようになった事実 は, 韓国の高分子研究も最近, 非常に活発になったの を裏書きするのだとい兄る．特に，多数の海外帰り拈 よび 40 歳代が主力をなしていることが特徵とい党る.

高分子企業中以は，規模の大きいのもあり，工場内

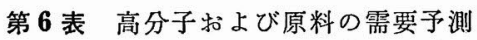
(単位: $1,000 \mathrm{t}$ )

\begin{tabular}{|c|c|c|c|c|c|}
\hline & \multirow{2}{*}{1977} & \multirow{2}{*}{1981} & \multirow{2}{*}{1986} & \multicolumn{2}{|c|}{ 年平均增加 } \\
\hline & & & & $77 \sim 81$ & $82 \sim 86$ \\
\hline PVC & 137.2 & 275.0 & 476.7 & 21.4 & 11.6 \\
\hline $\mathrm{PE}(\mathrm{LD})$ & 130.6 & 259.2 & 431.6 & 22.2 & 10.7 \\
\hline PE (HD) & 32.9 & 67.2 & 113.4 & 19.6 & 11.0 \\
\hline $\mathrm{PP}$ & 111.0 & 229.5 & 384.9 & 22.5 & 10.9 \\
\hline PS & 39.1 & 86.5 & 141.4 & 26.4 & 10.3 \\
\hline ABS & 6.8 & 15.6 & 26.9 & 30.6 & 11.5 \\
\hline SBR & 48.3 & 84.4 & 141.5 & 16.3 & 10.9 \\
\hline $\mathrm{BR}$ & 9.6 & 17.6 & 30.6 & 18.1 & 11.6 \\
\hline ラクタム & 94.9 & 125.6 & 149.3 & 6.3 & 3.5 \\
\hline AN & 115.3 & 158.5 & 195.2 & 7.8 & 4.2 \\
\hline TPA & 139.7 & 200.5 & 258.5 & 8.7 & 5.3 \\
\hline EG & 60.2 & 88.9 & 116.9 & 9.5 & 5.6 \\
\hline フタル酸 & 22.0 & 38.1 & 62.7 & 17.0 & 10.5 \\
\hline 塩化ビニル & 142.7 & 286.0 & 495.8 & 19.5 & 12.0 \\
\hline スチレン & 63.5 & 132.8 & 219.4 & 20.0 & 10.6 \\
\hline 石炭酸 & 8.5 & 15.9 & 27.2 & 21.1 & 11.3 \\
\hline PPG & 5.7 & 12.7 & 27.3 & 27.3 & 16.5 \\
\hline TDI & 3.6 & 6.6 & 13.0 & 16.0 & 14.6 \\
\hline
\end{tabular}

（韓国石油化学工業協会，1977）

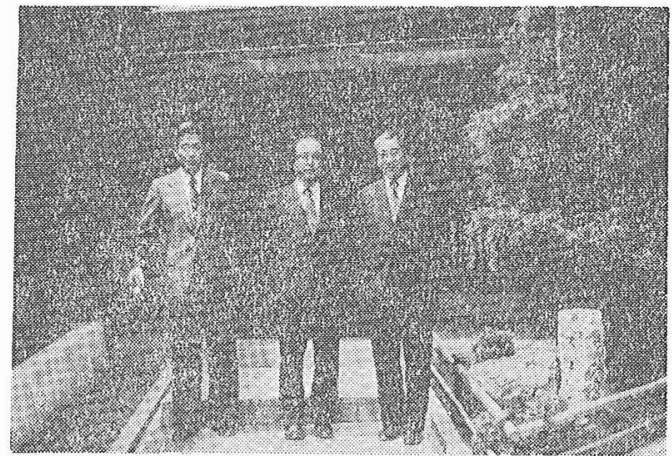

写真二左より 盧 益 三氏 (仁荷大学教授), 成 佐 慶氏 (韓国化学研究所所長), 中島章夫氏 (京都大学教授, 本 会会長), 京都六盛にて.

に研究室をるっているところる増古，特に最近は别個 の中央研究所を計画する企業の数も増加し，一部は建 設に着手しているものもある. 研究内容は, 重合方法 の改良，製造方式，製品改良之開発の段階だと予想さ れる。詳細は不明であるが，触媒の自体改良でアタッ クチック PP の副生量を $1.5 \%$ まで減らしたとか, ナイロン4を研究中だとかが伝兄られている。韓国科 学技術研究所 (KIST) で研究開発し，パイロット試験 をすませた VC-AN 共重合体の製造と紡系を工業化 中の企業もある.

特殊法人研究機関の 研究活動は活発である. '66 年 設立の KIST は総合研究所で一千余名の所員を有し， 多数の能力ある研究員が集まっている高分子部をむっ ているが，業界との関連研究が多く，内容と結果は公 表さ机ているのが少ない，前述の VC-AN 共重合体 の開発に成功し, イオン交換樹脂, 高分子膜, フッ素 樹脂，または sheet 成形，ポリェチレン利用などに相 当の業績をあげて拉り，高分子橋かけ理論，調節分解 高分子, 生体高分子の研究も進行中である. 韓国原子 力研究所の高分子グループは, 高分子と木材, 高分子 とコンクリートなどの複合，繊維に対するグラフトな ぞに相当の成果をあげ，電子線 Curable 塗料の研究 もしている. 新設の韓国化学研究所にも高分子部が設 置されているが，本格的活動は来年からと考克られ

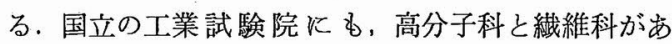
る.

韓国の大学全体で 75 年度の統計によると, 化学科 の数 24 , 工科の化学工学科, 工業化学科, 高分子工 学科の数は各々 $25,4,4$ であったが, その後, 工業 化学科の数が増加しつつあり, 高分子工学科を工業化 学科火改編する傾向も多くなっている. 高分子研究山 理科の化学科よりも工科の化学系学科の方が活発であ る. また大学院だけをもっている韓国科学院 (KAIS)

(681 頁へ続く) 


\section{文献}

1) 和田 正：日本ゴム協会誌，46，261 (1973)

2) 中島 功, 有我欣司：けい素樹脂 (1970); 庇目 暗：シリユーン樹脂 (1971)

3) J.F. Brown, G.H. Slusaczuk: J. Amer. Chem. Soc., 87, 931 (1965)

4）中島 功：有機合成協会誌，34，583(1976)

5）高見沢 棇：化学と工業，30，865（1977）
6) 伊藤光一：プラスチック，29[1] 34 (1978)

7) 伊藤光一：油化学, 26, 627 (1977)

8）小泉 淳: プラスチックマテリアル，18 [7] 33 (1977)

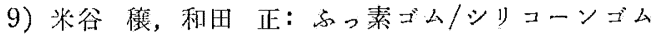
(1974)

10）伊藤邦雄：工業材料，25[8] 31 (1977)

11) Barry Arkles: Chemtech., 7, 766 (1977)

12) E. W. Colvin: Chem. Soc. Review, 7, 15 (1978)

\section{(676 頁より続く)}

（もち万ん各大学にも大学院がある）にも強力な高分 子研究グループがある.

紙面の関係上詳細怯省略し，最近 1,2 年間学会誌に 発表された論文を主にして分野別に題目だけを紹介す る。合成拉よび反応分野では，EVA に対するスチレ ソのグラフト重合，無機塩を使用するビニ儿重合，塩 素化反応 (Seoul 大), ナイロン6のモノマーキャステ イング,ナイロンに対するアクリル酸のグラフト，ラ クタムの陰イオン重合, ビニルシクロプロパン誘導体 のシジカル異性化重合, ブテン混合物の重合, 粘土表 面汇拈斿重合, ポリェチレングリコールーAN ブロ ック共重合, ポリオレフィン崩壞の動力学 (科学院),
含リンポリペプチド合成リン酸ビニル誘導体の単独 特よび共重合（高麗大），コロナ放電による重合，高 分子崩壊（仁荷大）ポリペプチド合成（漢陽大），ポ リイミド合成（東国大）などが女る，機能性高分子分 野では，膜（生体高分子，漢陽大，入イドロゲル，科 学院), イオン交換樹脂 (慶北大), 高分子キレート (漢陽大)，不然性䋐維（仁荷大）などが屴る。その他 物性・構造·工学分野では, 表面物性, ポリイソシア ナートの溶液物性（仁荷大），ポリペプチド（漢陽 大), 繊維の機珹的性質（嶺南大），複合材料（漠陽 大, 化荷大), NMR (Seoul 大), 特性化（亜洲工大) などを㘯げることができる。

an important new work in polymer science...

\title{
THERMODYNAMICS OF POLYMERIZATION
}

\author{
by HIDEO SAWADA \\ Daicel, Ltd., Osaka, Japan 416 pages, illustrated
}

- Thermodynamics of Polymerization is a comprehensive treatment of all major topics of thermodynanics and energetics as they relate to polymerization processes.

- As the study of polymerization processes now requires an understanding of these thermodynamics, this book is designed to answer the need for a thorough study of these aspects specifically.

- Intended primarily for use by chemists and chemical engineers in this field, Thermodynamics of Polymerization will also serve research workers seeking an introduction to a sulject other than their own specialty and polymer technologists pursuing insight into polymerization reactions.

- In addition, the book may serve as a classroom textbook at either the graduate or the advanced undergraduate level.

CONTENTS: Introductory Survey. Heat of Polymerization. Anionic Polymerization. Cationic Polymerization. Radical Polymerization. Polycondensation. Ring-Opening Polymerization. Equilibrium Polymerization. Copolymerization: Part 1. Copolymerization: Part 2. Polymer Degradation. Special Topics. 